\title{
L1 AND L2 READING ATTITUDES AND THEIR CONTRIBUTION TOWARD READING HABIT
}

\author{
Sri Rejeki Murtiningsih \\ English Language Education Department, Faculty of Language Education, \\ Universitas Muhammadiyah Yogyakarta, Indonesia \\ E-mail: jackie.murt@umy.ac.id
}

APA Citation: Murtiningsih, S. R. (2020). L1 and L2 reading attitudes and their contribution toward reading habit. Indonesian EFL Journal, 6(1), 27-34. doi: 10.25134/ieflj.v6i1.2635.

\begin{abstract}
The aims of the study are threefold. The first is to investigate the reading attitudes toward first language (L1) and second language (L2) in an English as a foreign language (EFL) context. The second aim is to find out the correlation between both variables. The last objective of the study is to find out the contribution of L2 reading attitude toward reading achievement. This study involved two sets of questionnaires adapted from Yamashita (2004) and Mikami (2016) and 177 freshmen, sophomore and junior English language education department students. The data revealed that means of reading attitude toward L1 and L2 are not significantly different with 2.60 and 2.65 respectively, and that reading attitude in L1 is strongly correlated with reading attitude in L2 $(r=0.637)$. An interesting finding of the present study pointed out that although students have positive attitude in L2, it does not automatically motivate them to spend their time reading. External factors such as teachers and specific reading programs both in L1 and L2 seem to play bigger roles in shaping students' reading attitudes. Pedagogical implications are also discussed

Keywords: Reading attitude in L1; reading attitude in L2; reading habit; external factors.
\end{abstract}

\section{INTRODUCTION}

A plethora of research has indicated that reading in L1 and L2 are strongly correlated to each other (Yamashita, 2007; Akbari, Ghonsooly, Ghanzanfari, and Shahriari, 2017; Sparks, Patton, Ganschow, and Humbach, 2012). A number of research had been conducted in different contexts in which English was considered as a foreign language. Yamashita (2007), for instance, asserts that if students have positive attitude to reading in L1, they will more likely have the same attitude toward L2 reading. This study coincides with Mori's (2002), who like Yamashita (2007), also conducted his study in Japan. Similarly, Granena, Munoz, and Tragant (2015) contend that positive attitude toward reading L1 has a positive impact on reading attitude in L2. This is in line with Akbari et al's (2017) study which argues that reading attitude in L1 and L2 among Iranian language learners is strongly correlated $(\mathrm{r}=0.7)$.

Studies also show that reading, both intensively and extensively, can lead to positive results. Nation $(2007,2009)$ asserts that the more reading students do, the larger their vocabulary would become, which in turn, will improve their English competence. A similar notion is proposed by Krashen (2004). These studies indicate that students who read a lot will likely have better achievement compared to those who read less. In terms of academic achievement, Akbari et al (2017) maintain that although L1 and L2 reading attitudes are highly correlated, only $\mathrm{L} 2$ reading attitude had significant contribution toward L2 reading achievement, not the $\mathrm{L} 1$.

Reading interest in Indonesia has been considered low. Claims have been made by many politicians about this issue as issued in newspapers, and said claims were based on the frequency on public library visits (CNN Indonesia, March 27, 2018). While this is a strong statement, credible and reliable research on the reading in Indonesia has been quite scant - if not none. Iftanti (2012) and Masduqi (2014)'s studies are among the very few research regarding reading areas in Indonesian contexts. Iftanti (2012) conducted a survey on students' habit in reading English books in and the results show that Indonesian students' reading habit is low. Another research in reading was conducted by Masduqi (2014) and claims that reading in university level in Indonesia is also low.

Although claims have been made, there has been very limited study on the level of reading attitude in L1 and L2 in Indonesia. An extensive study on reading habits, however, was conducted by Iftanti (2012) in university contexts with over 500 participants involved. The study mentions that "although the students have read English since elementary school, they do not indicate to have good reading habits" (p. 149). The particular study presented quite interesting data. For example, more than $50 \%$ of the participants showed that they read English books and other types of literature at least an hour every day, around $17 \%$ read less than an hour every day, more than $20 \%$ did not always 
read every day, and only $7 \%$ seldom read. In addition, the study also found that the participants read different types of English texts, e.g. comics, textbooks, nonfiction, poems, etc. both in printed forms or e-books.

While Iftanti's claim that the amount of time spent to read is one of the most important things to measure one's reading habit might be true, agreement has not been reached among scholars on how much time for someone to read to fall on the category of having a good or bad reading habit. Reading a book for an hour every day for pleasure can be a great achievement for a typical Indonesian student who spend 8 hours or more a day on campus or school. On one hand, Iftanti's (2012) study reveals that Indonesian students showed positive attitude toward reading EFL because the majority of the participants had considerably high reading habits. On the other hand, Iftanti's study also lacks information of the participants' reading habit or attitude in L1 and how they relate to their language achievements. Based on the above arguments, the present study aims to answer the following research questions:

1. What is students' reading attitude toward L1?

2. What is students' reading attitude toward L2?

3. How does L1 reading attitude correlate with the $\mathrm{L} 2$ reading attitude?

4. How does L2 reading attitude contribute to the L2 reading habit?

The study is expected to shed the light on the reading attitude of Indonesian students and investigate how the attitude in L1 and L2 play a role in their reading achievement.

\section{Theoretical Framework}

The theory underlining this study is a functional approach of attitude offered by Katz (1960) who defines attitudes as a tendency in which someone assesses some objects in a certain way. Attitude is observable because it can be expressed in verbal and nonverbal ways. When a person has a positive attitude toward something, he would have positive opinions and his behavior shows that he favors it. Katz (1960) argues that attitude comprises of three main components: affective, beliefs or cognitive, and behavior or action. Affective refers to "the intensity of feeling of [an] individual for or against" something (p. 168), which can be verbally expressed; therefore, it would be an opinion. Meanwhile, cognitive deals with the complexity of beliefs that an individual holds. Lastly, behavior or action is the manifestation of the attitude. According to Katz (1960), an individual with a favorable attitude may show different types of behavior. For example, two students may have positive attitude toward reading, but one would go and find books to read whenever he feels like reading, while the other students would read only if someone gives him a text. Similar studies on interaction between the components were also conducted by Ajzen and Fishbein (1977) and Lee and Schallert (2014). Out of these three components, affective and cognitive components play bigger roles on L2 proficiency compared to other predictors, i.e. personality and demographic components (Onwuegbuzie, Bailey, and Daley, 2010).

A myriad of research had been conducted in the affective components of L2 learning (Horwitz, Horwitz, \& Cope, 1986; Martinez, Aricak, and Jewell, 2008). One of the most influential studies in this area deals with L2 learning anxiety (Horwitz et al., 1986), which found that the intensity of anxiety can influence L2 learners' proficiency. Sparks et al (2012) conducted a longitudinal study on the influence of cognitive components in L1 and L2. The research shows that cognitive ability in L1 played an important role in cognitive ability not only in L1, but also in L2 proficiency. In the context of reading attitude in L1 and L2, Yamashita (2004), did not clearly state that he uses Katz's theory of functional approach of attitude, but he employed the three components to base his study. Yamashita's (2004) questionnaires, which is adapted in the present study, only used two components of Katz's (1960) theory, i.e. affective and cognitive components.

\section{Reading in $\mathrm{L} 1$ and $\mathrm{L} 2$}

Reading, while it is considered as a receptive skill, needs several skills to work at the same time. To be able to understand a text, an individual needs to accurately recognize what the words mean and understand how they work together (Babayigit, 2014). Many would find reading L1 texts to be easy; this, however, may not be necessarily true in reading $\mathrm{L} 2$ texts. Those who use characters in their L1 like Chinese, Korean, or Arabic language learners, for example, may have to learn to read the alphabetical letters when they learn other languages. Thus, they will have additional challenges to understand a totally different orthography. Those who use alphabets when learning an L2 will still have to deal with a grammatical structure which might be totally different from their L1.

A longitudinal study was conducted by Sparks et al (2012) which provided extensive exposure to their participants in their L1. It turns out that the exposure did not only improve their $\mathrm{L} 1$ reading achievement during a time span of 10 years, but their reading achievement contributed significantly toward their $\mathrm{L} 2$ reading achievement. This means 
that if a teacher exposes his students with L1 reading, this will somehow contribute to their L2 achievement. Their findings show that cognitive components (e.g. reading skills) used in L1 can be employed in the $\mathrm{L} 2$ reading.

Transfer of reading skills in L1 and L2 has been vastly researched. Keung and Ho (2009) argue that cognitive skills in L1 reading like phonological and letter-recognition are transferred to L2 reading. Their research revealed that students' knowledge in pronouncing words is quite useful when they read in L2. A similar notion is suggested by Edele and Stanant (2015) who state that two different languages might have a certain level of similarity which may allow an individual to transfer the knowledge from one language to another more easily. This will help an $\mathrm{L} 1$ reader to understand $\mathrm{L} 2$ texts better.

\section{Relations between reading attitude toward reading habit}

The notion of attitude influence behavior, such as engagement and frequency in reading, will highly likely lead to higher achievement (McKenna, Kear \& Ellsworth, 1995; Onwuegbuzie et al, 2010). Reading engagement and frequency is something that is observable and replicable, which refers to behavior. Research has shown inconsistent results regarding the relation between attitude and achievement. Martinez et al (2008) found that reading attitude is strongly positively correlated with reading achievement within a four month period. On the other hand, an interesting finding is offered by Camiciottoli (2001) which showed that despite a favorable reading attitude, the engagement shown by the participants was quite low. Lee and Schallert (2010) argue that reading frequency in L1 is strongly correlated with L1 reading achievement, and so is L2 reading frequency with $\mathrm{L} 2$ reading achievement. This is also in line with Spark et al (2012).

\section{Factors influencing reading attitude}

To understand reading attitude better, it is important to understand factors that influence them. An array of research found that several external factors significantly contributed to L2 reading attitude. Factors that can become the predictors include access to reading materials, teachers' support, reading instructions, and examination (Lee \& Scharllert, 2012; Briggs \& Walter, 2016; Spark et al, 2012). Access to reading materials can improve students' attitude toward reading because students can exercise their preference towards the types of texts that they want to read. In addition, encouragement from the authority figures like teachers can change students' attitude toward reading. Teachers' support can be in the form of reading programs or pedagogical practices that provide an environment for students to read.

Meanwhile, internal factors like gender, personality, and students' self-concepts, also influence reading attitude. Martinez et al (2008) surveyed 4,000 students and found that female students tend to have more positive attitude toward reading than male students, but the reasons for the differences remained unclear. Apparently, gender also became an internal predictor toward L2 achievement. Onwuegbuzie et al (2010) found that male students tend to have a lower level of L2 achievements. In addition to gender, students' personality is also one of the factors that influence reading attitude. Briggs and Walter (2016) and Onwuegbuzie et al (2010) mention that student autonomy and their willingness to work collaboratively with other people became predictors of reading attitude. Kartal (2011) found that some L2 learners felt that they were not able to perform well in L2 reading, which leads to learners having a negative attitude toward reading. On the other side, Martinez et al (2008) also found that internal factor such as age does not influence reading attitude. This finding is inconsistent with MacKenna et al's (1995) in which they maintain that as the students get older, their positive attitude toward reading can decline because "their beliefs that reading can be pleasurable are likely to compete with beliefs that other activities may be even more pleasurable" (p. 941).

\section{METHOD \\ Participants}

A total of 177 participants consisting of freshmen, sophomore, and junior students of an English Language Education Department at a private university in Indonesia were involved in the study. From these participants, 20 students were interviewed to get richer data and to find out further about their attitude in reading in L1 and L2.

\section{Instruments}

The reading attitude questionnaire was adapted from Yamashita (2004). The instrument consisted of two parts, affective reactions and cognitive reactions with seven and eight items respectively. The original questionnaires were written in English and was translated into the participants' L1. The translated version was consulted to two experts with doctorate degree and piloted to several undergraduate students, and some suggestions were given. After the questionnaires were revised, they were then tried out again to a different group of undergraduate students who were not potential participants. No suggestions were offered. 
Two sets of the same questionnaires were administered to find out participants' L1 and L2 reading attitude. The questionnaire used to investigate the $\mathrm{L} 1$ reading attitude was specifically written texts in the Indonesian language and the other set was stated texts in the English language, to avoid confusion among the participants. The questionnaires used to measure L2 reading attitude had four addition questions adapted from Mikami (2016). The questions were also translated into participants' L1. Mikami's questionnaire was an instrument that requires participants to write their answers. In general, the questions were related to participants' time spent to read English books outside the classroom, their motivation to read, and challenges they face when reading English books. With regard to the score of participants' reading achievement were taken from a standardized English test used by the institution. The test was a multiple choice format that consisted of 50 questions.

\section{Procedure and data analysis.}

The questionnaires were administered to potential participants a few days apart because the items in the questionnaire were only slightly different, distributing questionnaires a few days apart was aimed to minimize the participants' ability to remember the exact answers they had given in the first questionnaires.

\section{RESULTS AND DISCUSSION}

To answer the research questions previously proposed, the data are presented below:

\section{Reading attitude toward L1.}

Table 1 shows the computation results of the data in which the total mean of students' reading attitude toward L1 is 2.60. This means that although in general the students showed a positive attitude towards reading in L1, their attitude might not be strong enough to initiate reading an Indonesian book. The highest mean of the results of the L1 reading attitude questionnaire of the affective factor were Affective 3: Reading is enjoyable (3.01) ( $\mathrm{sd}=$ 0.715). As for the cognitive factor, the item Cognitive 6: I think reading many books [written in Bahasa Indonesia) enables us to acquire depth of knowledge and sophistication scored 3.24 (sd = $0.615)$. An interesting finding from the data was that although the students were enrolled in a department where most of the books used for classes were written in English, and the language of instruction was English, the participants still showed strong positive attitude toward Indonesian texts (Affective 3: Reading Indonesian books is enjoyable $=3.01$ ).

Another interesting finding about the students' reading attitude on the cognitive factor show that while all students were native Indonesians, they did not think that their reading ability was in advanced level (Cognitive 4: I think my reading level [in Indonesian] is advanced $=$ 2.81). In addition, the participants did not think that they could read in L1 quickly. As shown in Cognitive 1: I can read [in Indonesian] quickly, the mean was 3.08. This finding is quite surprising considering that they had been using the Indonesian language in their daily lives.

Table 1. Reading attitude toward L1

\begin{tabular}{lcccc}
\hline & $\mathrm{N}$ & Sum & Mean & Std. Deviation \\
\hline Affective 1 & 177 & 330 & 1.86 & .726 \\
Affective 2 & 177 & 281 & 1.59 & .695 \\
Affective 3 & 177 & 533 & 3.01 & .715 \\
Affective 4 & 177 & 359 & 2.03 & .829 \\
Affective 5 & 177 & 464 & 2.62 & .752 \\
Affective 6 & 177 & 381 & 2.15 & .836 \\
Affective 7 & 177 & 461 & 2.60 & .860 \\
Cognitive 1 & 177 & 546 & 3.08 & .760 \\
Cognitive 2 & 177 & 484 & 2.73 & .668 \\
Cognitive 3 & 177 & 487 & 2.75 & .635 \\
Cognitive 4 & 177 & 497 & 2.81 & .646 \\
Cognitive 5 & 177 & 523 & 2.95 & .629 \\
Cognitive 6 & 177 & 574 & 3.24 & .615 \\
Cognitive 7 & 177 & 498 & 2.81 & .702 \\
Cognitive 8 & 177 & 486 & 2.75 & .737 \\
Valid N & 177 & & 2.60 & \\
(listwise) & & & & \\
\hline
\end{tabular}




\section{Reading attitude toward $\mathrm{L2}$}

The data revealed that the total mean of students' reading attitude toward L2 or reading English books was, surprisingly, not significantly different from the $\mathrm{L} 1$ reading attitude, which is 2.65 . As the participants were English language education department, needless to say that the statement Cognitive 3: I think reading many books is advantageous to the study of my major received the highest mean (3.40). Similar to the L1 reading attitude, students also found that reading in L2
https://journal.uniku.ac.id/index.php/IEFLJ/index

was enjoyable $($ mean $=3.40$, $\mathrm{sd}=0.650)$. The complete results of the L2 reading attitude questionnaire can be seen on table 2 below. In the case of how students perceived their language skills, their perception of their L2 skills was quite similar to theirs of L1 skills with mean scores of 2.51 and 2.81 respectively. This particular statement is depicted in Cognitive 4: I think my reading ability [in English language] is advanced.

Table 2. Reading attitude toward L2

\begin{tabular}{ccccc}
\hline & $\mathrm{N}$ & Sum & Mean & Std. Deviation \\
\hline Affective 1 & 177 & 465 & 2.63 & .713 \\
Affective 2 & 177 & 290 & 1.64 & .686 \\
Affective 3 & 177 & 521 & 2.94 & .637 \\
Affective 4 & 177 & 464 & 2.62 & .729 \\
Affective 5 & 177 & 429 & 2.42 & .679 \\
Affective 6 & 177 & 398 & 2.25 & .816 \\
Affective 7 & 177 & 442 & 2.50 & .762 \\
Cognitive 1 & 177 & 416 & 2.35 & .604 \\
Cognitive 2 & 177 & 508 & 2.87 & .648 \\
Cognitive 3 & 177 & 601 & 3.40 & .650 \\
Cognitive 4 & 177 & 445 & 2.51 & .623 \\
Cognitive 5 & 177 & 550 & 3.11 & .517 \\
Cognitive 6 & 177 & 575 & 3.25 & .626 \\
Cognitive 7 & 177 & 450 & 2.54 & .707 \\
Cognitive 8 & 177 & 485 & 2.74 & .739 \\
Valid N & 177 & & 2.65 & \\
(listwise) & & & & \\
\hline
\end{tabular}

\section{Correlation between reading attitude toward} $\mathrm{L} 1$ and $\mathrm{L} 2$

To answer the third research question, a correlational analysis was run. The results show that there is a strong positive correlation between
$\mathrm{L} 1$ and $\mathrm{L} 2$ reading attitude $(\mathrm{r}=0.637)$. Also, the L1 and L2 reading attitude do not have a statistically significant linear relationship $(p=$ $0.619>0.001)$.

Table 3. Paired sample correlations

\begin{tabular}{ccccc}
\hline & & N & Correlation & Sig. \\
\hline \multirow{2}{*}{ Pair 1 } & $\begin{array}{c}\text { Mean_English \& } \\
\text { Mean_Indonesian }\end{array}$ & 15 & .637 & .011 \\
\hline
\end{tabular}

Table 4. Paired samples test

\begin{tabular}{|c|c|c|c|c|c|c|c|c|c|}
\hline & & \multicolumn{5}{|c|}{ Paired Differences } & \multirow{3}{*}{$\mathrm{t}$} & \multirow[b]{3}{*}{ df } & \multirow[b]{3}{*}{ Sig. (2-tailed) } \\
\hline & & \multirow[t]{2}{*}{ Mean } & \multirow[t]{2}{*}{$\begin{array}{l}\text { Std. } \\
\text { Deviation }\end{array}$} & \multirow[t]{2}{*}{$\begin{array}{l}\text { Std. } \\
\text { Error } \\
\text { Mean }\end{array}$} & \multicolumn{2}{|c|}{$\begin{array}{l}95 \% \text { Confidence } \\
\text { Interval of the } \\
\text { Difference }\end{array}$} & & & \\
\hline & & & & & Lower & Upper & & & \\
\hline $\begin{array}{l}\mathrm{Pa} \\
\text { ir } 1\end{array}$ & $\begin{array}{l}\text { Mean_Enalish- - } \\
\text { Mean_Jodonsi } \\
\text { an }\end{array}$ & $\begin{array}{l}.0526 \\
7\end{array}$ & .39010 & $\begin{array}{c}.1007 \\
2\end{array}$ & $\begin{array}{l}. \\
.16336\end{array}$ & 26870 & .523 & 14 & .609 \\
\hline
\end{tabular}




\section{Contribution of $\mathrm{L} 2$ reading attitude toward L2 reading habit.}

To find out the contributions of L2, Mikami's (2016) questionnaire was used. The results of the questionnaire were quite interesting. Of the 177 participants, 62 wrote that they did not read any English books aside from the ones assigned by their teachers for classes, although almost all of them stated that they had high interests in reading English books in their free time. The rest of the participants wrote that they read English books outside their class; however, 12 of them mentioned the novels that were read for classes, while the others wrote a wide array of books. Of those who wrote they read books for pleasure, 19 of them spent more than 5-12 hours a week to read.

With regard to the participants' reading achievement of the university's English proficiency test, it was found that their average score for this particular area is 410 , which is equal to 34 of TOEFL iBT or 4.5 of IELTS band. In the meantime, based on the rules and regulations set up by the department where the participants studied, the participants were required to obtain at least 500 of the university's English proficiency test to graduate. The score equals to 61 of TOEFL iBT or 6 of IELTS band.

\section{Discussion}

Based on the findings presented, there are some important notes to take regarding reading attitudes toward L1 and L2. First of all, it was quite surprising that while the participants had been using their L1 in all aspects of their life, their attitude toward L1 and L2 was not significantly different. Evidently, their attitude toward L1 may have contributed to the attitude toward L2, which means that if someone already has a positive attitude towards their L1, he will likely have a positive attitude toward the L2 they are learning. This is shown by the strong correlation between the two sets of data. This study was in support with Spark et al (2012) and Yamashita (2004). In addition, Yamashita (2004) states one's L1 reading attitude forms their L2 reading attitude.

Another important point to note from this study is that positive attitude in reading can manifest in a different form of behavior shown by the participants. For example, students who have positive attitude or have high interests in reading English texts did not automatically have a high motivation to read outside the class. This is in favor with Katz (1960) who suggests that students would display a variety of behavior although they have favorable attitude toward something. One student may decide to take charge of their own learning by making efforts in finding their own L2 reading texts, while others would wait for their teachers or parents to tell them to read and hand them the texts. The interaction between attitude and these different types of behavior can be found in this study, where students stated that they had high motivation to read and that they were aware that reading $\mathrm{L} 2$ texts would improve proficiency, and yet they did not read books other than what their teachers gave. In other words, the interaction between the affective factor (high interests in reading $\mathrm{L} 2$ books) may have been influenced by the cognitive factor (L2 vocabulary mastery), which then discourages many of these students to spend time to read English books.

The finding is also in support with Yamashita (2004), "merely thinking that reading is good for oneself does not constitute a sufficiently a strong motivation" (p. 13). This statement actually reflects what this present study found. The fact that some students listed the books used by the teachers for class purposes as the book(s) they read outside the class shows that those students still depend on teachers' instruction to read, which in turn would shape their reading attitude in the future. It gives a strong indication that although students were fully aware that they could have found free L2 books online, they waited until their teacher asked to read and provided them the books so they could read. This may have contributed to the mastery of L2 vocabulary, which eventually would influence their performance in reading tests.

Apparently, a positive reading attitude do not always relate to the awareness of improving the size of L2 vocabulary. For example, many of the participants stated that despite having high interests in reading in L2 to improve their L2 vocabulary, the participants did not make any or very little time to read. As a matter of fact, Krashen (2004) and Nation (2007, 2009) assert that the fastest way to improve L2 vocabulary is by reading. Thus, the interaction between reading attitude and awareness to read as shown by the data needs to be investigated further.

The implications that can be drawn from this study is that there should be a systematic effort from teachers and institution to maintain a positive reading attitude. Action can be taken to nurture the attitude, such as by providing them a variety of reading texts both in $\mathrm{L} 1$ and $\mathrm{L} 2$. The fact that reading attitude in $\mathrm{L} 1$ correlates with the one in $\mathrm{L} 2$ can be a starting point for teachers to encourage their students to read in L1, especially when the students state that their lack of L2 vocabulary 
mastery was the reason they spend very little time or no time to read. Teachers can include reading a wide variety of literature in their classes as assignment.

It is also important to take external factor, e.g. culture into account when it comes to reading. In many contexts in Indonesia, students' dependence on teachers or other influential figures can be a major challenge to foster or shape a positive attitude toward reading. Although students are expected to be more independent in the university contexts, the culture in which teachers become the center of learning can present a particular barrier to promote positive reading attitude.

While this study offers some interesting findings, it has some limitations that can be the focus of future research. The data for this study, i.e. reading performance were collected only at one point of the participants' study; therefore, the development of their L1 and L2 reading attitude and reading performance was unknown upon the data collection. A longitudinal study can be taken to see how the two major issues develop or fluctuate over time. The study only looked at reading attitude from affective and cognitive factors. Future research can explore other contributing factors toward reading attitude

\section{CONCLUSION}

This study presents the $\mathrm{L} 1$ and $\mathrm{L} 2$ reading attitude and how they correlate to each other as well as the contribution of L2 reading attitude toward students' reading achievement. The study comes to a conclusion that $\mathrm{L} 1$ and $\mathrm{L} 2$ reading attitude found that there was no significantly different mean between $\mathrm{L} 1$ and $\mathrm{L} 2$ reading attitude and that they have a strong relationship with each other. The study also found that the positive reading attitude toward L2 can manifest in a different way for different individuals. Apart from the affective and cognitive factors, other influencing factors especially external factors, such as teachers, book collection both written in L1 and L2, and classroom instructions also play an important role in shaping the reading attitude.

\section{ACKNOWLEDGEMENTS}

The author would like to thank to Universitas Muhammadiyah Yogyakarta for the research grants to conduct this study.

\section{REFERENCES}

Ajzen, I., \& Fishbein, M. (1977). Attitude-behavior relation: A theoretical analysis and review of empirical research. Psychological Bulletin, 84(5), 888-918.
Akbari, H., Ghonsooly, B., Ghanzanfari, M., \& Shahriari, H. (2017). Attitude toward reading: L1 or L2 or both. SAGE Open, 1-10.

Babayigit, S. (2014). The relations between word reading, oral language, and reading comprehension in children who speak English as a firs (L1) and second language (L2): a multigroup structural analysis. Reading and Writing, 28, 527544.

Briggs, J. G., \& Walter, C. (2016). Read on! Extensive reading and young second language learners' motivation and attitudes. Oxford: University of Oxford Department of Education.

Camiciottoli, B. C. (2001). Extensive reading in English: habits and attitudes of a group of Italian university EFL students. Journal of Research in Reading , 24(2), 135-153.

Edele, A., \& Stanat, P. (2016). The role of firstlanguage listening comprehension in secondlanguage reading comprehension. Journal of Educational Psychology, 108(2), 163-180.

Horwitz, E. K., Horwitz, M. B., \& Cope, J. (1986). Foreign language classroom anxiety. The Modern Language Journal, 70(2), 125-132.

Iftanti, E. (2012). A survey of the English reading habits of EFL students in Indonesia. TEFLIN Journal, 23(2), 2012.

Kartal, E. (2011). Foreign language teacher trainee's reading attitude. Social Behavior and Personality, 39(3), 345-360.

Katz, D. (1960). The functional approach to the study of attitudes. Oxford Journals, 24(2), 163-204.

Keung, Y.-C., \& Ho, C. S.-H. (2009). Transfer of reading-related cognitive skills in learning to read Chinese (L1) and English (L2) among Chinese elementary school children. Contemporary Educational Psychology, 34, 103-112.

Krashen, S. D. (2004). The power of reading: Insights from the research. Westport, CT: Heinemann.

Lee, J., \& Schallert, D. L. (2014). Literate actions, reading attitudes, and reading achievement: Interconnections across languages for adolescent learners of English in Korea. The Modern Language Journal, 98(2), 553-573.

Martinez, R. S., Aricak, O. T., \& Jewell, J. (2008). Influence of reading attitude on reading achievement: A test of the temporal-interaction model. Psychology in the School, 45(10), 10101022.

Masduqi, H. (2014). EFL reading in Indonesian universities: Perspectives and Challenges in Cultural Contexts. Journal of Teaching and Education, 03(03), 385-397.

Mikami, A. (2017). Students' attitudes toward extensive reading in the Japanese EFL context. TESOL Journal, 8(2), 471-488.

Mori, S. (2002). Redefining motivation to read in a foreign languae. Reading in a Foreign Language, 14(2), 91-110

Nation, I. (2009). Teaching ESL/EFL reading and writing . NY: Routledge. 


\section{Sri Rejeki Murtiningsih}

$L 1$ and $L 2$ reading attitudes and their contribution toward reading habit

Onwuegbuzie, A. J., Bailey, P., \& Daley, C. E. (2010). Cognitive, affective, personality, and demographic predictors of foreign-languae achievement. 94(1), 3-15.

Pratiwi , P. S. (2018). Minat baca masyarakat Indonesia masih rendah [Indonesian's reading rate still low]. CNN Indonesia.

https://www.cnnindonesia.com/gayahidup/20180326160959-282-285982/minat-bacamasyarakat-indonesia-masih-rendah.
Sparks, R. L., Patton, J., Ganschow, L., \& Humbach, N. (2012). Do L1 reading achievement and L1 print exposure contribute to the prediction of L2 proficiency? Language Learning, 62(2), 473-505.

Yamashita, J. (2004). Reading attitudes in L1 and L2, and their influence on L2 extensive reading. Reading in a Foreign Language, 16(1), 1-19.

Yamashita, J. (2007). The relationship of reading attitudes between L1 and L2: An investigation of adult EFL learners in Japan. TESOL Quarterly, 4l(1), 81-105. 